\title{
The Prevalence of Lactic Acid Bacteria in Sausages at Khartoum State
}

\author{
Nagwa B. Elhag ${ }^{1}$, El Rakha B. Babiker ${ }^{2}$, Ahmed A. Mahdi ${ }^{3}$ \\ ${ }^{1}$ Department of Food Hygiene and Safety, College of Public \& Environmental Health, University of Bahri, Khartoum North, Sudan \\ ${ }^{2}$ Food Research Centre, Microbiology and Biotechnology Department, Agricultural Research Corporation, Shambat, Sudan \\ ${ }^{3}$ Department of Botany and Agricultural Biotechnology, Faculty of Agriculture, Khartoum University, Shambat, Sudan
}

\begin{abstract}
Lactic acid bacteria (LAB) are useful microorganisms. They have been used in food preparation thousands of years ago. A total of 40 fresh sausage samples were collected randomly from 8 sources in Khartoum State, Sudan. These sources include (a) butcheries in Khartoum, Khartoum north, and Omdurman, (b) factory-processed sausages at retail outlets and (c) home-made sausages. The sausage samples were studied to count and identify LAB species associated with sausages samples. LAB counts were carried out on de Man and Rogosa (MRS) agar medium. The pure isolates of LAB isolates were characterized by using morphological properties, biochemical tests and their ability to ferment different sugars. The mean counts of LAB in butcheries samples ranged from $9.30 \times 10^{6} \mathrm{cfu} / \mathrm{g}$ to $3.64 \times 10^{7} \mathrm{cfu} / \mathrm{g}$, which was higher than the mean of factory-processed sausages $\left(\mathrm{mean} 2.12 \times 10^{5} \mathrm{cfu} / \mathrm{g}-4.41 \times 10^{6} \mathrm{cfu} / \mathrm{g}\right)$, which was, in turn, higher than the load shown by home-made sausages (mean $5.04 \times 10^{5} \mathrm{cfu} / \mathrm{g}$ ). LAB isolates were identified as Streptococcus cremoris (40\% of isolates), Enterococcus faecalis (20\%), Lactobacillus acidophilus (15\%), Lactobacillus delbruckii subsp. lactis (10\%), Lactobacillus delbruckii subsp. Bulgaricus (7.5\%), Lactobacillus jenseny, Lactobacillus vitulinus, and Streptococcus avium, each representing $2.5 \%$ of the isolates. The high counts of $L A B$ and the prevalence of beneficial LAB in sausage samples make this product a good source for industrial LAB which can be applied in the production of a wide range of fermented foods and pharmaceuticals.
\end{abstract}

Keywords: Beneficial LAB bacteria, Characterization of LAB, Enterococcus, Streptococcus cremoris, Fresh Sudanese sausages

\section{Introduction}

Lactic acid bacteria (LAB) are used for a long a time by man. LAB play an important role in food industry and food preservation. They are gram-positive, catalase negative, non spore-forming and anaerobic cocci or rod bacteria. These bacteria divided into homo-fermentative and heterofermentative according to the final product produced during fermentation [1]. LAB live in different environments rich in nutrients such as milk and milk products, meat, fermented products, beverages and vegetables. Also they will exist in soil, water, manure, sewage [2] and human [3]-[4]-[5]. Many researches were carried out on $\mathrm{LAB}$ and their benefits in different fields such as their role in production of fermented products as starter cultures to inhibit the spoilage bacteria and enhance the organoleptic characters of the final product [6], their ability to be use as propiotics [7], reduce cholesterol level [8], control intestine disorder [9], produce small organic compounds responsible for organoleptic properties [10], improve the immune system [11] and their role in processing of animal feeds like silage [12]-[13]. Beneficial LAB bacteria, especially Lactobacillus species can produce antimicrobial substances inhibit the growth of some pathogenic microorganisms [14]. As reported by [15] th these beneficial microorganisms are found to be most effective during periods of disease or stress and following antibiotic treatment. Also it has been recorded that they have ability to spoil different products such as meat, fish and beverage [16]-[17]. The aim of this research was the isolation and identification of LAB. To our best knowledge this the first study for isolation and identification of LAB from sausage samples.

\section{Materials and methods}

\subsection{Sampling}

A total of 40 sausage samples were collected from different eight sources: (a) butcheries in Khartoum, Khartoum North and Omdurman, (b) factory-processed sausages (F1, F2. F3, F4 factories) collected at retail outlets, and (C) homemade from household in Khartoum. Samples were collected in sterile ice cooled container and immediately transferred to the laboratory for microbiological analysis.

\subsection{Preparation of serial dilution, enumeration and isolation of $\mathrm{LAB}$}

Thirty grams of each sample of fresh sausages were vigorously homogenized in sterile bottles containing $270 \mathrm{ml}$ of peptone water and then blended for $30 \mathrm{sec}$ in sterile electric blender. Serial ten-folds dilutions were prepared according to the method described by [18] using the same diluents. Enumeration of LAB was detected using MRS agar medium (Hi-media Laboratories Pvt. Ltd. India). Readily prepared solidified MRS agar plates were inoculated with $0.1 \mathrm{ml}$ of suitable dilutions using spread method, and then incubated anaerobically by using anaerobic jars with gas generating kits (Oxoid BR 0038b) at $37{ }^{\circ} \mathrm{C}$ for 2-3 days [18]-[19]. After incubation colonies were counted using colony counter (Quebec colony counter) and recorded as colony forming unit (cfu) per gram fresh weight of each sample. Predominant isolates from different morphologically differences were selected and purified by repeated streaking on MRS agar. The pure cultures were streaked onto MRS slant agar, stored at $5^{0} \mathrm{C}$ for further 


\section{International Journal of Science and Research (IJSR) \\ ISSN (Online): 2319-7064}

Index Copernicus Value (2013): 6.14 | Impact Factor (2014): 5.611

studies and sub-cultured at two-month interval. LAB isolates were activated in MRS broth at $30 \mathrm{oC}$ for $24 \mathrm{~h}$ prior to use.

\subsection{Characterization of LAB isolates}

Characterization of the purified isolates was carried out using Bergeys Manual [20]- [21]-[18]-[22]. All purified isolates were subjected to gram staining, catalase test, growth at $15^{\circ} \mathrm{C}$ and $45^{\circ} \mathrm{C}$ in MRS broth [23]-[1], growth in $6.5 \%$ and $18 \% \mathrm{NaCl}$ in $\mathrm{MRS}$ broth, growth in $4.4 \mathrm{pH}$ and $9.6 \mathrm{pH}$ in MRS broth, production of gas from glucose and $\mathrm{NH} 3$ from arginine broth, production of acetoin in phosphate broth, action in litmus milk broth and fermentation of $1 \%$ sugars (amygdalin, arabinose, fructose, lactose, raffinose, salicin, sucrose, xylose, maltose, and mannitol).

\section{Results and Discussion}

Generally, the count of LAB in investigated samples was high (Table 1). The mean counts of LAB in butcheries samples ranged from $9.30 \times 10^{6} \mathrm{cfu} / \mathrm{g}$ to $3.64 \times 10^{7} \mathrm{cfu} / \mathrm{g}$, which was higher than the mean of factory-processed sausages (mean $2.12 \times 10^{5} \mathrm{cfu} / \mathrm{g}-4.41 \times 10^{6} \mathrm{cfu} / \mathrm{g}$ ), which was, in turn, higher than the load shown by home-made sausages (mean $5.04 \times 10^{5} \mathrm{cfu} / \mathrm{g}$ ). LAB counts of the investigated sausage samples were within the range of $2.12 \times 10^{5} \mathrm{cfu} / \mathrm{g}$ to $3.64 \mathrm{x}$ $10^{7} \mathrm{cfu} / \mathrm{g}$. The counts of LAB in Mhom (a traditional meat sausage in Thailand), were $6.0 \times 10^{6}-1.0 \times 10^{7} \mathrm{cfu} / \mathrm{g}$ [24], The high counts of these bacteria in this study may be due to the suitable conditions that favor LAB growth, or they may be introduced from raw meat, spices, equipments and air during handling, processing, marketing and storage.

A total of forty isolates were presumptively identified as LAB according to the morphological and biochemical tests (Table 2). The identified isolates were gram-positive, rods or cocci, non-motile, non-spore forming, catalase-negative, oxidase-negative, and producing acid from glucose with no gas. Isolates were identified as:

Streptococcus cremoris represented $40 \%$ of the total isolates. It is used in dairy products to create cheese. It is known as L. lactis but it is more commonly known as Streptococcus cremoris. It gives the cheese its characteristics flavour and odour. It is selected for manufacturing cheese such as cheddar, Colby, cottage cheese, cream cheese and camembert cheese as well as other dairy products like cultured butter, sour cream and kefir. It can be used as single culture or in mixed strain cultures with other LAB. Some strains of $S$. cremoris produce the bacteriocin diplococcin, its activity spectrum was restricted to $S$. cremoris and $S$. lactis strians and non of the grampositive or negative strains were inhibited [25].

This research makes a critical step towards understanding and manipulating L. cremoris for improving the flavour, texture and preservation of cheese produced manually.

Enterococcus faecalis represented $20 \%$ of the isolates. Enterococcus faecium and Enterococcus faecalis strains are used as probiotics. Enterococci belong to LAB and they are of importance in foods due to their involvement in food spoilage and fermentation as well as their utilization as probiotics as in human. They are used as starter cultures in the food industry as well as health supplements and probiotics by the pharmaceutical industry. This status requires a careful evaluation on the bases of pathogencity of the strains used to produce food and pharmaceuticals.

The pathogencity status may produce clinical symptoms similar to staphylococcal intoxication. The infectious dose is probably high (more than $10^{7}$ organisms). Food sources include sausages, cheeses, meat pie, pudding and raw milk. Entrance into the food chain is due to under processing and/ or poor and unsanitary food production [26].

Enterococci are poor acidifiers, and in traditional sausages of high $\mathrm{pH}$ they find good conditions for survival and growth [27]. However, they are still considered as GRAS (Generally Recognized as Safe) microorganisms [28]. Studies pointed out those meat enterococci, especially Enterococcus faecium, have a much lower pathogenicity potential than clinical strains, and some strains of E. faecium are already used as starter cultures or probiotics [27]-[29]. However the safety of the genus Enterococcus is difficult to assess, because certain strains are also associated with human disease. Enterococci are commensals of the mammalian tract, but at the same time can also occur in and dominate the microflora of foods [30]. The presence of enterococci in the sampled sausages indicates the poor hygienic quality of raw materials used in sausage production [28] also can be used as an indicator of faecal contamination [30].

Lactobacillus acidophilus represents $15 \%$ of the isolates. It is a benevolent type of microbe that can help improve the balance of bacteria in our bodies. We get acidophilus from plant sources as whole wheat foods, onion, tomato, banana and garlic. Honey always contains varying concentration of acidophilus [31]. Eating foods containing acidophilus can help to treat and prevent diarrhea caused by bacteria. It also fights the vaginal bacteria that cause yeast infections to women. It also helps in lowering cholesterol and helps to digest lactose in lactose sensitive people. The therapeutic potential of these bacteria in fermented dairy products is dependant on their survival during manufacture and storage. L. acidophilus has been reported to be beneficial organisms that provide excellent therapeutic benefits. It is present in the form of the tablets and suppositories and as freeze dried granules, powder and capsules.

Lactobacillus delbruckii subsp. lactis (10\%) is none pathogenic. In fact it is widely used in the food industry and can be found in yoghurt, milk, vegetables and cheese [32].

Lactobacillus delbruckii subsp. Bulgaricus (7.5\%) is important in the dairy industry as starter cultures for the production fermented milk, yoghurt and cheese [33]-[34].

g- Lactobacillus jenseny, Lactobacillus vitulinus, and Streptococcus avium, each representing $2.5 \%$ of the isolates.

The microbiological quality of Thai fermented meat sausages was studied by [24]. They identified the predominant LAB as Lactobacillus curvatus, L. delbrueckii, L. acidophilus, L. paracasei, L. brevis, L. mesentroides, L.

\section{Volume 4 Issue 11, November 2015}




\section{International Journal of Science and Research (IJSR) \\ ISSN (Online): 2319-7064}

Index Copernicus Value (2013): 6.14 | Impact Factor (2014): 5.611

plantarum, L. farciminis, Carnobacterium divergens, Pediococcus pentosaceus and Enterococcus canakci. The predominant LAB strains associated with Turkish dry fermented sausage were isolated and identified as Lactobacillus lactis subsp. lactis, L. curvatus subsp. curvatus, L. brevis, L. fermentum, Wieisiella viridescens, $L$. delbrueckii subsp. delbruceckii, Wieisiella confusa, Lactobacillus collinoides, and Leuconostoc mesentroides subsp. mesentriodes/ dextranicum [35]. They claimed that the dominant microflora in sausage is Lactobacillus plantarum. Lactococcus lactis subsp. lactis, L. casei, and Enterococcus casseliflavus, and Leuconostoc mesenteroides were isolated from fresh sausages stored at $40^{\circ} \mathrm{Cfor} 10$ days [36].

The whole Results explain that there is a diversity of LAB species associated with fresh Sudanese sausages sold in Khartoum State. Some of these LAB species can be used as a probiotics in the food industry as well as pharmaceuticals.

\section{References}

[1] L. Axelsson.. Lactic acid bacteria: Classification and physiology. In: Lactic Acid Bacteria. Microbiological and Functional Aspects. (S. Salminen, and A. Von Wright, eds), Third edition. Marcel Dekker. New York, Basle, pp 1-72. 2004.

[2] W. H. Holzapfel, P. Haberer, R..Geisen, J. Björkroth and U. Schillinger. Taxonomy and important features of probiotic microorganisms in food nutrition. Am. J. Clin. Nutr. 73:365s-373S, 2001.

[3] J. Schrezenmeir, and M. de Vrese. Probiotics, prebiotics, and synbiotics-approaching a definition. Am. J. Clin. Nutr. 73: 361S-364S, 2001.

[4] G. Reid. Propiotic agents to protect the urogenital tract against infection. Am. J. Clin. Nutr. 73: 437S-443S, 2001.

[5] R. Martín, G. H. Heilig, E. G.; Zoetendal, H Smidt and J.M. Rodríguez, Diversity of the Lactobacillus group in breast milk and vagina of healthy the women and potential role in the colonization of the infant gut. Journal of Applied Microbiology. Vol 103: 2638-2644, 2007.. Doi: 10.1111/j.1365-2672.2007.03497.x.

[6] J. Metapxopoulos, M. Mataragas, and E.H. Drosinos. Microbial interaction in cooked cured meat products under vacuum or modified atmosphere at $4 \mathrm{oC}$. Journal of Applied Microbiology. 93 (3): 363-373, 2002.

[7] R. Temmerman, B. Pot, G. Huys and J. Swings. Identification and antibiotic susceptibility of bacterial isolates from probiotic products. Int. J. Food Microbiol. 81:1-10, 2002.

[8] M. S. Jachson, A. R.; Bird and M. C. Orist. Comparison of two selective media for the detection and enumeration of lactobacilli in human faeces. $\mathrm{J}$. Microbiol. Methods. 51: 313-312, 2002.

[9] G. R Gibson and R. Fuller. Aspects of in vitro and in vivo research approaches directed toward identifying probiotics for human use. J. Nutr. 130: 391S-395S, 2000.

[10]E. Caplice, and G.F. Fitzgerald. Food fermentations: role of microorganisms in food production and preservation. International Journal of Food Microbiology. 50:131-149, 1999.
[11]E. Isolauri, Y. Sűtas, P. Kankaapää, H. Arvilommi, S. Salminen. Probiotics: effects of immunity. Am. J. Cin. Nutr. 73: 444-450, 2001.

[12]F. Driehuis and S. J. W. H Oude Elferink.. The impact of the quality of silage on animal health and food safety: a review. Vet. Quart. 22: 212-217, 2000.

[13] M. Holzer, E. Mayrhuber, H. Danner and R. Braun. The role of lactobacillus buchneri in forage preservation. Trend Biotechnol. 21:282-287, 2003.

[14] S. M. Saad, C. Vanzin, M. N. Oliveria, and B. D. Franco. Influence of lactic acid bacteria on survival of Escherichia coli 0157: H7 inoculated Minas cheese during storage at $8.5^{\circ} \mathrm{C}$. Journal of Food Protection. 64: pp. 1151-1155, 2001.

[15]Ch. K. Yost and F. M. Nattress Molecular typing technique to characterize determinant lactic acid bacteria community on vacuum-packaged. International Journal of Food Microbiology. 72: 97-105, 2002.

[16] J. M. Jay. Fermentation and fermented dairy products, pp, 113-130. In Modern Food Microbiology. $6^{\text {th }}$ edition. An Aspen Publication, Inc. Gaithersburg.USA, 2000.

[17] S. Q. Liu. Review article: Practical implications of lactate and pyruvate metabolism by lactic acid bacteria in food and beverage fermentation. Int. J. Food Microbiol. 83: 115-131, 2003.

[18] W. E. Harrigan. Laboratory Methods in Food and Dairy Microbiology. Academic press. USA, 1998.

[19]I. Kiss. Testing Methods in Food Microbiology, A Textbook, Elsevier, New York, 1984.

[20] P. H. A. Sneath, N. S. Mair, M. E. Sharp, and J. G. Holt, (eds). Berg's Manual of Systematic Bacteriology. Vol. 2, (Baltimre: Williams and Wilkins) ,1986.

[21]G. I. Barrow and S.J. Feltham, R.K.A.. Manual for Identification of Medical Bacteria, third edition. Cambridge University Press, England,1993.

[22] S. Salminen, A.V. Wright and A. Ouwehand. Lactic Acid Bacteria. Microbiology and Functional Aspects. Tird Edition. Marcel Dekker, Inc. New York. Basel, 2004.

[23] J. G. Holt, N. R. Krieg, P. H. A. Sneath,. J. T. Staleyand S.T. Williams. Bergey's manual of determinative bacteriology, $9^{\text {th }}$ ed. P. 529, p 566. Williams and Wilkins. M D. 1994.

[24] W. Samappito, B. Leenanon and E. L. Robert. Microbiological characteristics of "Mhom", a Thi traditional meat sausage. The Open Food Science Journal. 5: 31-36, 2011.

[25] G. P. Davey and B.C. Richardson.. Purification and Some Properties of Diplococcin from Streptococcus cremoris 346. Vol 41 (1): 84-89, 1981.

[26] Food-Info. Enterococcus spp and E. faecalis, E. faecium, $1999 . \quad$ http://www.foodinfo.net/uk/bact/enter.htm. Source The bad bug book http://www.cfsan.fda.gov/ mow/intro.html.

[27] M. Hugas, M. Garriga and M.T. Aymerich. Functionality of enterococci in meat products. International Journal of Food Microbiology. 88: 223 233, 2003.

[28] G. Giraffa. Enterococci from foods. FEMS Microbiol. Rev. 26:163-171, 2002.

[29] B. Martin, M. Garriga, M. Hugas and T. Aymerich. Genetic diversity and safety aspects of enterococci from 


\section{International Journal of Science and Research (IJSR) \\ ISSN (Online): 2319-7064}

Index Copernicus Value (2013): 6.14 | Impact Factor (2014): 5.611

slightly fermented sausages. J. Appl. Microbiol. 98:1177-1190, 2005.

[30] C.M. Franz, W. Holzapfel and M.E. Stiles. Enteroccoci at the crossroads of food Safety. International. Food Microbiology. 47:1-24, 1999.

[31] M.M Aween, Z. Hassan, B.J. Muhialdin, H.M. Noor and Y.A. Eljamel. Evaluation on antibacterial activity of Lactobacillus acidophilus strains isolated from honey. Am. J. Applied Sci., 9: 807-817, 2012.

[32]H. El Kafsi, J. Binesse, V. Loux, J. Buratti, S. Boudebouze, R. Deryn, S. Kennedy, N. Galleron, B. Quinquis, Batto. Jean-Michel, B. Moumen, E. Maguin, and M. van de Guchte,. Lactobacillus delbrueckii ssp. lactis and ssp. bulgaricus: a chronicle of evolution in action. doi:10.1186/1471-2164-15-407, 2014. http://www.biomedcentral.com/1471-2164/15/407.

[33] J. R. Klein, C. Ulrich, U. Wegmann, E. Meyer-Barton, R. Plapp and B. Henrich. Molecular tools for the genetic modification of dairy lactobacilli. System Appl Microbiol. 18, 493-503, 1996.

[34]P. Courtin and F. O. Rul.. "Interactions between microorganisms in a simple ecosystem: yogurt bacteria as a study model". Le Lait 84: 125-134, 2003. doi:10.1051/lait:2003031.

[35]G. C. Adiguzel, and M. Atasever. Phenotypic and Genotypic Characterization of lactic acid bacteria isolated from Turkish dry fermented sausage. Romanian Biotechnological Letters 14 (1): 4130-4138, 2009.
[36] L. Cocolin, K.. Rantsiou, L. Lacumin, R. Urso, C. Cantoni, and G. Comi,. Study of the ecology of fresh sausage and characterization of population of lactic acid bacteria by molecular methods. Applied and Environmental Microbiology. 70 (4): 1883-1894, 2004. doi: 10.1128/AEM.70.4.1883-1894.2004.

\section{Author Profile}

Dr. Nagwa Babiker Elhag Khalifa received the B. Sc degree in Food Science and Technology from Alexandria University- Egypt in 1993, Faculty of Agriculture, M.Sc. degree in Food Microbiology from University of Khartoum Faculty of Agriculture - Sudan in 2003 and PhD degree in Food Microbiology and Biotechnology from University of Khartoum-Sudan Faculty of Agriculture in 2013. During this period I stay teaching in different Universities. Now I join University of Bahri - Food Hygiene and Safety teach and doing different researches.

Professor El Rakha Bashir. Babiker received the B. Sc degree in Food Science and Technology from University of Khartoum Faculty of Agriculture, M. Sc and $\mathrm{PhD}$ degree in Food Microbiology from Britain. Now she joined Food Research Center, Shambat. Sudan.

Professor Ahmed Ali Mahdi received the B. Sc degree in Food Science and Technology from University of Khartoum Faculty of Agriculture, M. Sc and PhD degree in Food Microbiology from Britain. Now he joined Sert University- Libya.

Table 1: Sources and LAB counts isolated on MRS medium

\begin{tabular}{|c|c|c|}
\hline Sample No & Sample source & $*$ Mean LAB counts $($ cfu $/ \mathrm{g})$ \\
\hline 1 & Khartoum butcheries & $9.30 \times 10^{6}$ \\
\hline 2 & Khartoum North butcheries & $9.79 \times 10^{6}$ \\
\hline 3 & Omdurman butcheries & $3.64 \times 10^{7}$ \\
\hline 4 & $* *$ Factory 1 & $2.93 \times 10^{5}$ \\
\hline 5 & $* *$ Factory 2 & $2.23 \times 10^{5}$ \\
\hline 6 & $* *$ Factory 3 & $2.12 \times 10^{5}$ \\
\hline 7 & $* *$ Factory 4 & $4.41 \times 10^{6}$ \\
\hline 8 & Homemade & $5.04 \times 10^{5}$ \\
\hline
\end{tabular}

* Mean of 5 replicates.

** Factory samples at retail outlet.

LAB: lactic acid bacteria 


\section{International Journal of Science and Research (IJSR) \\ ISSN (Online): 2319-7064}

Index Copernicus Value (2013): 6.14 | Impact Factor (2014): 5.611

Table 2: Presumptive Identification of LAB isolated from sausage samples collected from different sources

\begin{tabular}{|c|c|c|c|c|c|c|c|c|c|c|c|c|c|c|c|c|c|c|c|c|c|c|}
\hline \multirow[b]{2}{*}{ 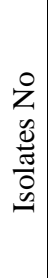 } & \multirow[b]{2}{*}{$\begin{array}{l}0 \\
0 \\
0 \\
0 \\
0 \\
\tilde{U} \\
0 \\
0 \\
0\end{array}$} & \multirow[b]{2}{*}{ 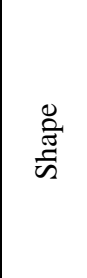 } & \multirow[b]{2}{*}{$\begin{array}{l}0 \\
0 \\
0 \\
0 \\
0 \\
000 \\
\vdots \\
0 \\
0 \\
0 \\
0 \\
0\end{array}$} & \multirow[b]{2}{*}{ 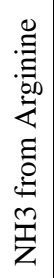 } & \multicolumn{2}{|c|}{ Growth at } & \multirow[b]{2}{*}{ 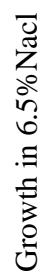 } & \multirow[b]{2}{*}{$\left|\begin{array}{c}\bar{D} \\
\tilde{z} \\
0 \\
0 \\
\infty \\
\Xi \\
. \Xi \\
\Xi \\
z \\
0 \\
0 \\
0\end{array}\right|$} & \multirow[b]{2}{*}{ 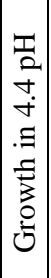 } & \multirow[b]{2}{*}{ 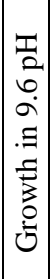 } & \multirow[b]{2}{*}{ 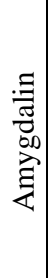 } & \multirow[b]{2}{*}{ 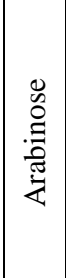 } & \multirow[b]{2}{*}{ 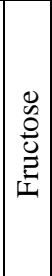 } & \multirow[b]{2}{*}{$\begin{array}{l}0 \\
\stackrel{0}{0} \\
\stackrel{0}{0} \\
\stackrel{\Xi}{\Xi}\end{array}$} & \multirow[b]{2}{*}{ 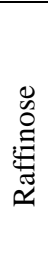 } & \multirow[b]{2}{*}{ 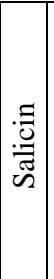 } & \multirow[b]{2}{*}{ 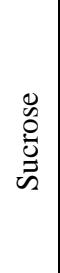 } & & & & & \\
\hline & & & & & $15^{\circ} \mathrm{C}$ & $45^{\circ} \mathrm{C}$ & & & & & & & & & & & & 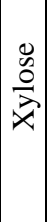 & 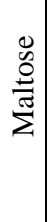 & $\begin{array}{l}\overline{\stackrel{O}{\Xi}} \\
\stackrel{\Xi}{\Xi} \\
\Sigma\end{array}$ & 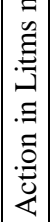 & $\begin{array}{l}\frac{\tilde{u}}{\tilde{J}} \\
\frac{\tilde{n}}{n}\end{array}$ \\
\hline 1 & KhB1 & Cocci & - & - & + & - & - & - & - & - & + & VW & + & - & + & - & - & - & + & - & + & S. cremoris \\
\hline 2 & KhB2 & Cocci & - & - & + & - & - & - & - & - & + & VW & + & - & + & - & - & - & + & - & + & S. cremoris \\
\hline 3 & KhB3 & Cocci & - & - & + & - & - & - & - & - & + & VW & + & - & + & - & - & - & + & - & + & S. cremoris \\
\hline 4 & KhB4 & Rod & - & - & - & + & - & - & - & + & + & - & + & + & - & + & + & - & + & - & + & L. deblruckii sub lactis \\
\hline 5 & KhB5 & Cocci & - & - & + & - & - & - & - & - & + & VW & + & - & + & - & - & - & + & - & + & S.cremoris \\
\hline 6 & KNB1 & Cocci & - & + & + & + & + & - & + & + & + & VW & + & + & + & + & + & - & + & - & + & E. faecalis \\
\hline 7 & KNB2 & Rod & - & + & - & + & + & - & + & + & + & - & + & + & + & + & + & - & + & - & + & L.acidophilus \\
\hline 8 & KNB3 & Cocci & - & + & + & + & + & - & + & + & + & VW & + & + & + & + & + & - & + & - & + & E.faecalis \\
\hline 9 & KNB4 & Rod & - & + & + & - & - & - & - & - & - & - & + & + & - & + & - & - & + & - & + & L.deblruckii sub lactis \\
\hline 10 & KNB5 & Cocci & - & + & + & + & + & - & + & + & + & VW & + & + & + & + & + & - & + & - & + & E.faecalis \\
\hline 11 & OB1 & Cocci & - & - & + & - & - & - & - & - & + & VW & + & - & + & - & - & - & + & - & + & S.cremoris \\
\hline 12 & OB2 & Cocci & - & - & + & - & - & - & - & - & + & VW & + & - & + & - & - & - & + & - & + & S.cremoris \\
\hline 13 & OB3 & Cocci & - & - & + & - & - & - & - & - & + & VW & + & - & + & - & - & - & + & - & + & S.cremoris \\
\hline 14 & OB4 & Cocci & - & - & - & + & + & - & $\mathrm{W}$ & $\mathrm{W}$ & + & - & + & + & - & + & + & - & + & - & & S. avium \\
\hline 15 & OB5 & Cocci & - & - & + & - & - & - & - & - & + & VW & + & - & + & - & - & - & + & - & + & S. cremoris \\
\hline 16 & LB1 & Cocci & - & + & + & + & + & - & + & + & + & VW & + & + & + & + & + & - & + & - & + & E. faecalis \\
\hline 17 & LB2 & Cocci & - & - & + & - & - & - & - & - & + & VW & + & - & + & - & - & - & + & - & + & S. cremoris \\
\hline 18 & LB3 & Cocci & - & - & + & - & - & - & - & - & + & VW & + & - & + & - & - & - & + & - & + & S. cremoris \\
\hline 19 & LB4 & Cocci & - & + & + & + & + & - & + & + & + & VW & + & + & + & + & + & - & + & - & + & E. faecalis \\
\hline 20 & LB5 & Cocci & - & - & + & - & - & - & - & - & + & VW & + & - & + & - & - & - & + & - & + & S.cremoris \\
\hline 21 & MB1 & Cocci & - & + & + & + & + & - & + & + & + & VW & + & + & + & + & + & - & + & - & + & E. faecalis \\
\hline 22 & MB2 & Cocci & - & - & + & - & - & - & - & - & + & VW & + & - & + & - & - & - & + & - & + & S. cremoris \\
\hline 23 & MB3 & Rod & - & + & + & - & - & - & - & - & - & - & + & + & - & - & - & - & + & - & + & L.. delbruki sub bulgaricus \\
\hline 24 & MB4 & Rod & - & + & + & - & - & - & - & - & - & - & + & + & - & - & - & - & + & - & + & L. delbruki sub bulgaricus \\
\hline 25 & MB5 & Cocci & - & + & + & + & + & - & + & + & + & VW & + & + & + & + & + & - & + & - & + & E. faecalis \\
\hline 26 & GB1 & Rod & - & + & - & + & + & - & + & + & + & - & + & + & + & + & + & - & + & - & + & L. acidophilus \\
\hline 27 & GB2 & Rod & - & + & - & + & + & - & + & + & + & - & + & + & + & + & + & - & + & - & + & L. acidophilus \\
\hline 28 & GB3 & Rod & - & + & - & + & + & - & + & + & + & - & + & + & + & + & + & - & + & - & + & L. acidophilus \\
\hline 29 & GB4 & Rod & - & + & - & + & + & - & + & + & + & - & + & + & + & + & + & - & + & - & + & L. acidophilus \\
\hline 30 & GB5 & Rod & - & + & - & + & + & - & + & + & + & - & + & + & + & + & + & - & + & - & + & L. acidophilus \\
\hline 31 & WB1 & Rod & - & + & - & + & + & - & - & - & + & - & + & - & - & + & + & - & $\mathrm{d}$ & - & - & L. jenseny \\
\hline 32 & WB2 & Rod & - & - & + & - & - & - & - & $\mathrm{W}$ & + & - & + & + & + & + & + & - & + & - & - & L. $\quad$ vitulinus \\
\hline 33 & WB3 & Rod & - & + & + & - & - & - & - & - & - & - & + & + & - & + & - & - & + & - & + & L deblruckii sub lactis \\
\hline 34 & WB4 & Cocci & - & - & + & - & - & - & 8 & - & + & $\mathrm{vW}$ & + & - & + & - & - & - & + & - & + & S. cremoris \\
\hline 35 & WB5 & Cocci & - & - & + & - & - & - & - & - & + & VW & + & - & + & - & - & - & + & - & + & S. cremoris \\
\hline 36 & HB1 & Cocci & - & + & + & + & + & - & + & + & + & VW & + & + & + & + & + & - & + & - & + & E. faecalis \\
\hline 37 & HB2 & Rod & - & + & + & - & - & - & - & - & - & 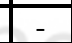 & + & + & - & + & - & - & + & - & + & L. deblruckii sub lactis \\
\hline 38 & HB3 & Cocci & - & - & + & - & - & - & - & - & + & VW & + & - & + & - & - & - & + & - & + & S. cremoris \\
\hline 39 & HB4 & Cocci & - & - & + & - & - & - & - & - & + & VW & + & - & + & - & - & - & + & - & + & S. cremoris \\
\hline 40 & HB5 & Rod & - & + & + & - & - & - & - & - & - & - & + & + & - & - & - & - & + & - & + & L. delbruki sub bulgaricus \\
\hline
\end{tabular}

Legend:

(-)Negative Reaction

(+) Positive reaction

(w)Weak reaction

(vw) Very weak reaction

(d) Delayed reaction

Volume 4 Issue 11, November 2015 www.ijsr.net

Licensed Under Creative Commons Attribution CC BY 